\title{
Body, Sensuousness, Eros and the New Aesthetic Order from Schiller to Rushdie $^{1}$
}

\section{ABSTRACT}

In the present article, I look into the culture-building power of Eros from Schiller's ideas of "the aesthetic state of mind" in Letters on the Aesthetic Education of Man, through the Pre-Raphaelites' eroticism to the nineteenthcentury fin de siècle aestheticized homoeroticism and beyond. I argue that eroticism is a reaction to the increasing sense of alienation brought about by bourgeois modernity. The "moments" and texts used to illustrate the thesis that eroticism shaped an alternative order are far from exhausting a very large list which could add nuances to the argument. The body is one of the essential aspects tackled, since eroticism cannot be conceived in its absence. The body may be an object of desire around which imagination weaves its yarn, or a blank page to be inscribed, or a danger zone, or a hypertrophied space projected by the lover's longing for fusion. Eroticism in Salman Rushdie's novels is the focus of my approach after a survey of some landmarks of erotic imagination. I argue that his novels are a new stage of the imagination infused by Eros. The article probes into how two centuries of aesthetic modernity have been shaped by the reality principle proposed by Schiller and how that essentially erotic model has suffered changes in time.

\section{Abstract}

1 This work was supported by the strategic grant POSDRU/89/1.5/S/62259, Project "Applied Social, Human and Political Sciences" co-financed by the European social fund within the Sectorial Operational Program Human Resources Development 2007-2013. 


\section{The Perils of the Modern Age and the Aesthetic Reshaping of Civilization}

The modern age is marked by a growing sense of insecurity, disorder and looseness, which reach severe forms of violence and oppression lurking under the glossy surface of order, justice, democracy and progress. There are even moments and longer periods when the dark side of the modern seems to prevail.

In The Gay Science, first published in 1882, through the parable of the madman searching for God, Nietzsche declared that God was dead at the hands of human murderers, and in the aftermath of this affirmation the predicament of the modern individual and society has been to manage without a transcendental dimension in an age plagued by two world wars, conflicts, a cold war, followed by many other local and global outbursts of violence. A less overtly pernicious side of the modern is insidious consumerism, whose "collateral damage" ${ }^{2}$ is analyzed by Zygmunt Bauman in his most recent book.

Long before Nietzsche, in 1795, Friedrich Schiller had felt and expressed the urgent need that modern civilization be reshaped according to a new reality principle. In Eros and Civilization, Herbert Marcuse argues that in Letters on the Aesthetic Education of Man, Schiller, under the impact of Imannuel Kant's Critique of Judgement, aimed at "a remaking of civilization by virtue of the liberating force of the aesthetic function" (180). Marcuse shows that this aesthetic solution to the problem of the modern individual and civilization, which started to take shape in the mideighteenth century with the emergence and development of aesthetics, was a reaction to the predominance in European culture of Prometheus, "the archetype-hero of the performance principle" (161). Being such an archetype, Prometheus crystallized centuries of a culture which valued productivity, progress and reason through the repression of any truths that ran contrary to its principle. In opposition to that, the discipline of aesthetics and the aesthetic dimension, which is so crucial in Kant's philosophy, rely on sensuousness. The archetypes of this dimension are, according to Marcuse, Orpheus and Narcissus, who are "symbols of a non-repressive erotic attitude toward reality" (167).

When Schiller wrote his Letters in late eighteenth century, the pressing need for reshaping, and thus healing civilization was also voiced by Herder, Hegel and Novalis, who developed the concept of "alienation" in order

2 In Collateral Damage: Social Inequalities in a Global Age (2011), Zygmunt Bauman furthers his theory of "liquid modernity," launched in 2000. Bauman shows that consumerism liquefies the solidity of the individual and of community by seducing us in a very insidious way. 
to draw attention to the alarming dehumanizing effects of a mechanized system. Against alienating technology, only a new liberating model could heal the wounds of the modern individual and civilization. Therefore, all these writers and philosophers embarked on a quest for an aesthetic solution to a political problem. Indeed, if viewed from this angle, their aesthetics had deep political implications. In the nineteenth century, the modern continued to develop along these two contrasting principles, which in Five Faces of Modernity Matei Călinescu considers to be two sides of a dualistic modernity: one is bourgeois and the other aesthetic.

\section{Orpheus and Narcissus, Eros and Creation}

Orpheus, who is at the same time committed to the underworld, and therefore to Thanatos, has the power to set the world free through song. Thus, he becomes the archetype of the poet as both liberator and creator. According to Marcuse, Narcissus, and the whole set of attitudes deriving from his archetypal stance which is called "narcissism," "denotes a fundamental relatedness to reality which may generate a comprehensive existential order" (169). It is through this liberating and non-repressive principle and through these two archetypes that aesthetics opposes the performance principle, which underpins technological progress, whose consequences proved to be gradually and seriously dehumanizing.

The discipline of aesthetics installs an order of sensuousness, which is essentially corporeal, against the order of reason; its underlying logic is the logic of gratification against that of repression. However, as Marcuse argues, the fatal enemy of lasting gratification is time, and the Orphic and Narcissistic model is one of beauty which cancels the flow of time, arresting and transfixing its flux.

The Orphic and the Narcissistic complete each other in a model of erotic harmony and fusion: a balance is struck between the objective and the subjective world, between the individual and nature within and without. Through song, Orpheus defeats death, the great enemy, "so that the constrained and constraining matter releases the beautiful and playful forms of animate and inanimate things" (Marcuse 194). Marcuse argues that, by reinforcing the logic of gratification, the liberating function of the aesthetic and its playful nature, Narcissus typifies "the erotic surrender to beauty" (194).

\section{The Body, Sexuality and Eros}

Marcuse speaks about the "self-sublimation of sexuality," which "implies that sexuality can, under specific conditions, create highly civilized human 
relations without being subjected to the repressive organization which the established civilization has imposed upon the instinct" (204). The German philosopher argues that when sexuality is seen beyond its function of reproduction as a means of "obtaining pleasure from zones of the body," "the primacy of the genital function is broken" (205) and thus sexuality is conceptually transformed into Eros.

Thus, the whole body becomes the playing ground of Eros. Being a source and substance of Eros, its receptivity must intensify, its sensuousness must grow and its erogenous zones must be activated through play. As Marcuse shows, Plato's Symposium celebrates the sexual source and substance of spiritual things. Diotima alleges that Eros makes one beautiful body desire another and eventually all beautiful bodies. Relying on $\mathrm{Pla}-$ to's arguments and making the necessary connections, Marcuse contends that "there is an unbroken ascent in erotic fulfilment from the corporeal love of one to that of the others, to the love of beautiful work and play, and ultimately to the love of beautiful knowledge" (211). Eros has a culturebuilding power, which is non-repressive sublimation, and "the biological drive becomes a cultural drive" (Marcuse 212).

\section{Eroticism, Death, Fusion, Dissolution and Transgression}

According to Georges Bataille, erotic activity is the highest form of play and the very antithesis of work. Bataille sees it not only in opposition to work but also to reproduction. To a very large extent, the views of Marcuse and Bataille in what concerns Eros meet in the idea that Eros expects no return and is a form of self-surrender to a moment which, as both philosophers suggest, transfigures its temporariness, almost freezing the flux of time out of a desire to restore a lost unity.

Bataille argues that eroticism springs from our awareness of death, which is at the same time an awareness of our incompleteness, and this urges us to look for the only fusion we may achieve this side of the grave, in which both body and soul enter. Being fusion, erotic love is also dissolution and mingling. While animals respond to reproductive instincts when they have sex, humans crave for a deeper and more complex fusion through eroticism, which is an essential and defining human attitude. Both Marcuse and Bataille argue that eroticism is inextricably tied in with death. In a very subtle and ambivalent way, eroticism gives us an intimation of death and through it a glimpse into an imagined space beyond life and death.

Bataille insists on the transgressive nature of eroticism, which must break social order and conventions. Its transgressive spirit associates it with sorcery, and both are in "opposition to the established sacred order" (97). Since the lover feels the strong need to possess the beloved, and if 
that is not or no longer possible, to kill rather than lose the object of one's passion, or even kill oneself, eroticism is intimately intertwined with violence and sacrifice. In rich metaphorical language, Bataille says that "the woman in the hands of her assailant is despoiled of her being. With her modesty she loses the firm barrier that once separated her from others and made her impenetrable" (102).

\section{Nineteenth-Century Aestheticized Eroticism AND HOMOEROTICISM}

The nineteenth century built on Schiller's ideas. An important landmark of its aestheticism was the Pre-Raphaelite movement. Set up in 1848, the Pre-Raphaelite Brotherhood was interested in literature and the arts at the same time. The Pre-Raphaelite artists contended that the British arts of their times were stale and boring, and their aim was to renew them and to restore their lost meaning. Not only did the Pre-Raphaelites emancipate painting from its academic conventionality, but they also freed the body from its prison. Religious scenes were rendered in a way in which Virgin Mary and Archangel Gabriel, for instance, appear as corporeal, as bodies under thin garments.

John Everett Millais's painting Ophelia draws on Shakespeare's Hamlet. After the death of her father, Polonius, mad and abandoned Ophelia, who gathers flowers and slips into a brook, is eventually dragged down to the murky depths by her garments. In Millais's painting, Ophelia's dressed body is almost completely immersed in water, her loose hair is under, flowers are swimming around, and only her face, the upturned palms of her hands and her breasts are above. In this painting, Ophelia's drowning body, and the "bodies" of the floating flowers soon to drown, immersed in the larger "body" of nature, express Ophelia's tragic fate, beautifying it. The body's immersion into water may be the equivalent of an erotic cosmic fusion and a return to the womb. The self-annihilation Ophelia could not achieve by fusing her body with her lover's is achieved through this self-annihilation into the larger body of nature, which is also a form of fusion.

In "Life-in-Love" Dante Gabriel Rossetti celebrates life in the body, and that body is not one's own but the lover's: "Not in thy body is thy life at all / But in this lady's lips and hands and eyes" ("The House of Life"). Rossetti echoed this eroticism in his paintings, and as the century progressed, Aestheticism grew more and more articulate in the views of the late-nineteenth-century artists.

Baudelaire's desire for sensuality, his constant probing into the relationship between art and life and into the nature of modern art in his 
essay The Painter of Modern Life, and later Walter Pater's book The Renaissance: Studies in Art and Poetry, provided fin de siècle artists with an outline for their aestheticized eroticism. Baudelaire portrayed the charming, refined, seducing and decadent dandy, and in 1884 Joris-Karl Huysmans wrote $\grave{A}$ rebours, a refined novel of fin de siècle decadence, which emulated a whole generation of artists in "the naughty yellow 1890s" and whose lascivious and cynical aestheticism was echoed by Oscar Wilde's The Picture of Dorian Gray, a key text of art for art's sake and homoeroticism, which came out in 1891. The erotic desire in these fin de siècle novels was, in the Victorian cultural and social context dominated by homophobia, alarmingly transgressive. Basil in Wilde's novel aestheticizes homoeroticism in a codified manner, by relating it to a cultural ideal exalted by Walter Pater. He speaks about his desire for Dorian Gray filtering it through the Greek ideal of male beauty:

Unconsciously he defines for me the lines of a fresh school, a school that is to have in it all the passion of the romantic spirit, all the perfection of the spirit that is Greek. The harmony of soul and body—how much that is! We in our madness have separated the two, and have invented a realism that is vulgar, an ideality that is void. Harry! If you knew what Dorian Gray is to me. (10)

Basil pleads for a new idealism, which draws not only on non-mimetic principles, but also on an essential homoerotic ideal of fusion between body and soul.

\section{Body, Eros and ERoticism in Rushdie's Novels}

In Midnight's Children, the novel where Rushdie felt he had found a voice through Saleem Sinai, the novel's narrator, there is a close connection not only between the individual and history, but also between his body and history, his body and the nation's, so that history leaks from Saleem's. However, the nation is divided, and so is the body. In the opening of Midnight's Children, Saleem's birth, a very corporeal act, coincides with "the precise instant of India's arrival at independence," but "there were gaps" (9). Through those gaps, Saleem's body "tumbled forth into the world," "mysteriously handcuffed to history." This first page is a retrospect: now Saleem is thirty-one years old, and his body feels "crumbled" and "overused." He tells his story against the clock to give it a meaning, which also means synthesis across gaps, fissures, crevices and new frontiers, because he admits that absurdity is what he fears most (9).

In The Moor's Last Sigh, the body of the Moor, the main character, who is also the novel's narrator, is a "megalopolis." In the hyperbolic key 
which is possible in Rushdie's novel of magic realism, the Moor grows at the same pace as the city of Bombay and as fast as India, anyway too fast for a human body's biology to cope with the speed, echoing the nation's similar problems of coping with speed, hybridity and change. Sensual Aurora Zogoiby, the Moor's artist mother, portrays her son in a series of paintings, a lot of them murals which are palimpsestic evocations of an India as fantastic and hybrid as the Moor. When he describes Aurora's paintings, which are imaginary projections of a country called "Palempstine" or "Mooristan," the author uses ekphrasis on a large scale in order to aestheticize this imaginary place of the mind. ${ }^{3}$ The Moor's Last Sigh is the novel in which Rushdie aestheticized his fiction through sublimation for the first time, a project he continued with self-conscious zeal in The Ground beneath Her Feet and The Enchantress of Florence.

The Ground beneath Her Feet is pervaded by the myth and model of Orpheus. Ormus Cama, the novel's key figure, is a rock'n'roll guitarist of Indian origin, who travels to England, starts a career there, and then leaves England for America to pursue it with his lover Vina Apsara by his side. Ormus is a mid- to late-twentieth-century Orpheus, whose music fuses the gaps of the novel's space, which is under permanent threat of devastating calamity. If Saleem in Midnight's Children fears absurdity, Ormus in The Ground beneath Her Feet fears the disaster of worlds in collision. $\mathrm{He}$ develops "double vision," and when he stops seeing the two worlds as separate, he imagines an apocalyptic end of the two colliding worlds. Ormus and Vina are in symbiotic connection, and it is only in song that they unite beyond tension, only through song that they manage to fuse a world full of crevices, fissures, gaps, and shaken by literal and metaphoric earthquakes. Vina herself is not only Eurydice, but a female Dionysus and Orpheus at the same time. The consuming passion of the two Orpheuses (Ormus and Vina) is the novel's core of meaning and strength. Ormus's developing asceticism sublimates their largely unconsumed sexual passion into song, while Vina's voice on the stage shouts her carnal desire, sublimating it into music. Apart from their passion sublimated into Orphic song, there is the sexual liaison between Vina and Rai Merchant, the novel's narrator, who sublimates it into his photographs and especially into the narrative of the novel. There is also the problematic but eventually triumphant love between Rai and Mira, a younger version of Vina.

Eroticism in the novel is polymorphous; sexuality is sublimated through the aesthetics of rock'n'roll, the soundtrack of the last decades

3 For a more detailed approach to this aspect, see Dana Bădulescu, "Bolovanul istoriei se rostogoleşte în opera lui Salman Rushdie” at http://www.sferapoliticii.ro/sfera/164/ art11-Badulescu.php. 
of the twentieth century, which both shakes and fuses the world, which unites Vina and Ormus beyond this side of the grave, and which throws Mira into Rai's arms to love. The Ground beneath Her Feet sees the art of rock'n'roll not just as what it was in the last decades of the twentieth century, but it transforms it into a new aesthetic order. It is this order with its mythic Orphic roots that governs the world of the novel not through repression but through rock'n'roll performance and gratification.

In Shalimar the Clown, the potentially happy love between Boonyi and Shalimar the Clown, whose actual name is suggestively Noman, ends tragically. Their love starts as consuming passion, a form of Eros as Georges Bataille conceived it. Bataille argues that "above all it is consumption that joins individuals most closely" (100). Boonyi and Shalimar the Clown are attracted so inescapably and at such an early age that they defy and break all social norms. Their secret trysts are preceded by moments of erotic longing, and in the love-making scenes their bodies fuse with each other and also cosmically with nature, fulfilling the erotic dream of recovering a lost unity. Eventually, their secret is discovered and the community has to decide the measures to be taken against their transgression. The answer is marriage, but Boonyi is not happy with a limiting horizon, and she looks for satisfaction in a mirage offered by Max Ophuls, the American ambassador. Boonyi's infidelity sets Shalimar the Clown in a killing mood, which he projects as a possibility in their most passionate moments. The possessive need, which Bataille sees as linked with the idea of death, urges Boonyi's husband to pursue a carefully planned series of killings which ultimately lead him to his wife, his most wanted victim. As Bataille argues, "if the lover cannot possess the beloved, he will sometimes think of killing her; often he would rather kill her than lose her" (103).

The body itself is a danger zone in the novel. Although India/Kashmira's young and fresh body is caressed by her father, and the daughter treasures those memories, the shadow of death and the spectre of terrible danger hang over the father-daughter love. Indeed, Max Ophuls's life is cruelly terminated by Shalimar the Clown, leaving a large amount of their love unconsumed. Boonyi translates the geography of Kashmir into her love for her husband Shalimar the Clown's body, speaking about "his valleys, his gardens, his flowing streams, his flowers, his stags, his fish" (197). Echoing this way of encoding declarations of love and erotic pleasure into the charted geography of maps, Max's love for Boonyi, never reciprocated, turns her body into a map of his world, over which he makes public political declarations which put his career and even life in jeopardy. Boonyi's body when she is forty-four, just before she is killed by Shalimar the Clown, is "the story of her life" and she wants her husband "to read the book of her nakedness, before he did what he had come to do," and when he comes, Shalimar the 
Clown reads her body and holds it "in his hands" (317-18). Boonyi strips herself naked for her husband, waiting for him, knowing that he will come to take his long-promised revenge and kill her. As Bataille argues, there is a close connection between love-making and sacrificial acts. It is this erotic connection that urges Boonyi's husband to cut his wife open with his knife, which is the killing weapon of his choice. Indeed, the knife is a weapon redolent with erotic symbolism since, as Bataille shows, eroticism "seeks intimate knowledge of nakedness - knowledge of the wound of physical being-whose opening deepens with each contact" (102). Boonyi's stripping herself naked in preparation for this sacrificial ritual is completed by Shalimar the Clown's stabbing of her body, which becomes an equivalent of love-making. In Bataille's terms, "the lover strips the beloved of identity no less than the blood-stained priest his human or animal victim" (102).

\section{Rushdie’s GHOSTLY Bodies}

Bodies also dwell in other bodies in Rushdie's fiction. Parents' bodies can dwell in their children's bodies until their own bodies become ghostly. The ghost of a character can dwell in the body of another, turning it into a phantom. In The Moor's Last Sigh, Aurora Zogoiby is "her dead mother's phantom, doing her deeds, speaking in her departed voice” (10). Belle's

night-walking daughter was keeping her mother alive, giving up her own body for the departed to inhabit, clinging to death, refusing it, insisting on the constancy, beyond the grave, of love-that she had become her mother's new dawn, flesh for her spirit, two belles in one. (10)

The body of India/Kashmira in Shalimar the Clown is described as a beautiful reflection in the mirror. Mirror effects multiply in the sense that while looking at her own reflection on the glass surface, the young woman discovers that her body is the feminine version of her father's, and that frequently turns her on. Later in the novel, Shalimar the Clown sees Boonyi the mother in India/Kashmira the daughter, and he is deeply moved and perplexed. When she changes India for Kashmira, the name she finds out her mother gave her at birth, Kashmira discovers her mother's body inhabiting hers in moments when she grieves the loss of the mother. In other scenes she feels that both her now dead mother and father dwell in her body, and her double name seems to reflect their coexistence in her body. This capacity to accommodate several bodies in one makes the bodies of Rushdie's characters metamorphic, which is a condition the writer considers to be an essential feature of his hybrid and migrant characters. Indeed, it is important and charged with meanings: this doubleness or even 
multifariousness of the body may also be read as palimpsestic, and the palimpsest has aesthetic and political connotations. Related to the body, the palimpsest is a metaphor of layers of meaning coexisting in the body of the text, in which the colonial past and postcolonial present coexist. Thus, the "ghostliness" of the characters' palimpsestic bodies adds to the rather sinister sense of the past haunting the present as a corporeal presence.

\section{RushdiE's EROTICIZED GEOGRAPHY}

Countries and cities read as lovers' bodies in Rushdie's fiction. In The Moor's Last Sigh, India is figured out as a mother, or else as the male character's first love, which can never be forgotten, no matter how hard one may try, and despite the bitter-sweet experiences it offered him in the "disorienting" story of The Ground beneath Her Feet. In the same novel, England is seen as a clutching lover called "Tar Baby," which keeps you in her strong grip, and never lets you go. Ormus calls it "stuck love" (276). However, urged by his woman-lover Vina, Ormus extricates himself from Tar Baby's strange embrace, and flies to America. Rai feels that "Langston Hughes's country that never existed but needed to exist-with that, like everyone else, I was thoroughly in love" (419), although Ormus's "double vision" reveals to him America's less nice face, which Rai is also able to see. America's dangerously seducing femininity keeps Rhinehart addicted to its "valley of the Dollybirds" (58), which is the narrator's means of eroticizing the projection of America in Rushdie's novel Fury. Indeed, although Malik Solanka, the protagonist of Fury, is also seduced by America, Rhinehart, his friend, is literally killed by his addiction to the charm of this country, which is essentially erotic. However, eroticism blends here with an awareness of the beloved country's corrupting and destructive Thanatos force: "To be seduced by what one loathed was a hard destiny" (200), reflects Solanka standing by the freshly dug grave of his friend.

Since his transcultural imagination steps across frontiers to project places of the mind, Florence adds to the erotically charged imaginary maps charted by Rushdie in The Enchantress of Florence. Mogor dell'Amore's enamoured description of the Italian city in its Renaissance heyday as an absolutely irresistible seductress plunges the reader into an eroticized topography:

"Imagine a pair of woman's lips," Mogor whispered, "puckering for a kiss. That is the city of Florence, narrow at the edges, swelling at the centre, with the Arno flowing through between, parting the two lips, the upper and the lower. The city is an enchantress. When it kisses you, you are lost, whether you be a commoner or a king." (176) 
Rushdie blends Eros with Thanatos according to an Orphic model. The erotically inviting female characters and the eroticized places of his fiction are ambivalent: they may be both innocent and corrupt, evil witches in a very disturbing way, like Qara Köz / Lady Black Eyes, the Enchantress in Rushdie's novel set in Florence and in India, and projecting an America which was at that time only a dream.

Rushdie designedly set The Enchantress of Florence not only at the confluence of two worlds and a dream, but also in the sixteenth-century Renaissance. Rushdie's twenty-first-century imagery relates to the Renaissance imagery and projects America. In this novel, maybe more than in other Rushdie novels, or in a different way, imagination projects and creates worlds and fills them with dreams. Thus, Akbar, the last Mughal emperor, himself an Enchanter, imagines a queen of unsurpassed beauty, whom he calls Jodha. Being created through "a pure act of will" (59), Jodha assumes a corporeal existence which seems to be more "real" than "reality" itself. The projection of Jodha, Akbar's longing for her while he is away, his coming back to her and their love-making scenes are charged with an eroticism which steps across more than one line. Jodha's fictitiousness steals the histories of the emperor's fellow wives, who envy her on that account. Jodha is also a sorceress, "the sorceress of herself" (62), and sometimes she performs her acts of "ungiculation" to inscribe the magic of her "reality" onto Akbar's body and thus "enhance the act of love." "No living woman" can perform "ungiculation" as well as Jodha can until Akbar confesses that "in the loneliness of his army tent, he would close his eyes and imitate her movements, would imagine his nails moving on his body to be hers, and be aroused" (64-65). By imagining Jodha's body, engaging it in erotic games of inscriptions on his own body performed by Jodha's and his own nails claiming to be hers, Akbar, himself a projection, mirrors the writing of the novel and its eroticized space.

The Enchantress of Florence teems with magic and magicians, sorcerers, enchanters and artists, both male and female. Akbar, Quara Köz/Lady Black Eyes, who eventually usurps Jodha and erases her, the other enchantresses in the novel, Mogor dell'Amore, who tells the story, these and others imbue the space with their eroticized artifacts and tales. Dashwanth and his community of painters at Akbar's court literally invent Mughal Hindustan and paint the emperor's soul (148). It is art that projects the world, and thus projected, the world comes into being. So enmeshed in his art is Dashwanth that he literally vanishes into the world of his last painting, which he titles "Qara-Köz-Nama, the Adventures of Lady Black Eyes." After he puts all his art passion in this final picture, urging his creation to breathe and transferring his own way of looking at her onto the face of one of the figures in the painting, Dashwanth vanishes beyond and into it, 
never to be seen again. Almost all the pictures of Qara-Köz-Nama disappear with him. However, Daswanth's "trick" of vanishing into the world of his own creation is discovered. Above everything, Dashwanth's immersion in his own painting is an act of love: "instead of bringing a fantasy woman to life, Dashwanth had turned himself into an imaginary being, driven (as the emperor had been driven) by the overwhelming force of love" (159). Akbar, the emperor who has created Jodha in his own imagination, understands, approves and orders that Dashwanth be left to dwell in the world he projected out of love: "If the borderline between the worlds could be crossed in one direction, Akbar understood, it could also be crossed in the other. A dreamer could become his dream" (159). Through the sublimation of sexuality into the eroticized space of the novel, the whole world is aestheticized as an echo of the Renaissance and its celebration of the body. Florence itself is the personification of a seducing woman, and the forms of seduction and gratification in the novel multiply as the narrative progresses.

Through eroticizing the body and infusing the whole universe of fiction with a culture-building Eros, Rushdie, who sees himself as "a translated man" ${ }^{4}$ caught in a rather uncertain space between several languages and cultures, across borders, like Nabokov, Kundera, Derrida, Borges (to give only a few examples), has engaged in a literary project based on (self-) sublimation through Eros and the achievement of a new aesthetic order. Rushdie has absorbed both Eastern and Western cultures, and those cultures have been largely shaped by religions. The scandal around The Satanic Verses has made it very clear that he is a secular thinker and writer interested in religion, myth and superstition as story. To him nothing is, though anything may become, sacred. Through eroticism, Rushdie's stories acquire physicality, a dimension which is further refined by aesthetic subtleties.

\section{CONCLUSION}

Aesthetic modernity, a reaction to bourgeois modernity, has been shaped by the Orphic and Narcissistic model of harmony and fusion, which strikes a balance between the objective and the subjective world, between the individual and nature. Through song, Orpheus defeats death, the great enemy. Reinforcing the logic of gratification, the liberating function of the aesthetic and its playful nature, Narcissus typifies the erotic surrender

4 When he probes into his British Indian identity and the issue of the English language, Rushdie argues that "having been borne across the world, we are translated men" (Imaginary Homelands 17). For a detailed discussion of Rushdie and his characters as "translated men," see Dana Bădulescu, "Rushdie the "Translated Man"” at http://www. sferapoliticii.ro/sfera/166/art09-Badulescu.php. 
to beauty. These two archetypes underlie a principle which informed literature and the arts in the last two centuries from Schiller's Letters on the Aesthetic Education of Man through the Pre-Raphaelites' eroticism, Baudelaire's projection of the sensual refined dandy and the fin de siècle aestheticized homoeroticism of Joris-Karl Huysmans and Oscar Wilde.

Rushdie's novels aim at aesthetic synthesis by sublimating sexuality into Eros and thus create an order of aesthetic balance as a solution to the crisis of the contemporary individual and society, whose dehumanizing effects have grown more and more rampant since Schiller spoke about "the aesthetic state of mind" and "the aesthetic education of man" in 1795. Rushdie's sublimations are essentially erotic. For most of his characters, love is erotic longing and projection. His eroticized geography translates a sense of cosmic union. His characters' sublimated sexuality is dangerously transgressive. Shalimar the Clown insists on consuming love and on the connection between Eros and sacrifice. The Moor's Last Sigh, The Ground beneath Her Feet and The Enchantress of Florence aestheticize Eros through ekphrasis and palimpsestic textuality, orphic song, fusion of the lovers' bodies and souls through music, or arty sorcery.

\section{WORKS CITED}

Bataille, Georges. Essential Writings. Ed. and trans. Michael Richardson. London: SAGE, 1998. Print.

Baudelaire, Charles. The Painter of Modern Life and Other Essays. Ed. and trans. Jonathan Mayne. London: Phaidon, 1995. Print.

Bauman, Zygmunt. Collateral Damage: Social Inequalities in a Global Age. Cambridge: Polity, 2011. Print.

Călinescu, Matei. Cinci fețe ale modernităţii: Modernism, Avangardă, Decadență, Kitsch, Postmodernism. Bucureşti: Univers, 1995. Print.

Huysmans, Joris-Karl. Against Nature. Trans. Robert Baldick. London: Penguin, 2004. Print.

Kant, Immanuel. Critique of Judgement. Trans. James Creed Meredith. Oxford: Oxford UP, 2007. Print.

Marcuse, Herbert. Eros and Civilization: A Philosophical Inquiry into Freud. Boston: Beacon, 1966. Print.

Nietzsche, Friedrich. The Gay Science. Trans. Walter Kaufmann. New York: Vintage, 1974. Print.

Pater, Walter. The Renaissance: Studies in Art and Poetry. New York: Dover, 2005. Print.

Rossetti, Dante Gabriel. "The House of Life: 36. Life-in-Love.” Ballads and Sonnets London: Ellis and White, 1881. Representative Poetry 
Online. University of Toronto Libraries, 13 Mar. 2002. Web. 10 May 2012.

Rushdie, Salman. The Enchantress of Florence. London: Vintage, 2009. Print.

---. Fury. London: Vintage, 2002. Print.

---. The Ground beneath Her Feet. London: Vintage, 2000. Print.

---. Imaginary Homelands. London: Granta Books, 1991. Print.

---. Midnight's Children. London: Vintage, 1995. Print.

---. The Moor's Last Sigh. New York: Pantheon, 1995. Print.

---. Shalimar the Clown. London: Jonathan Cape, 2005. Print.

Schiller, J. C. Friedrich von. Letter XXII. Letters upon the Aesthetic Education of Man. Bartleby.com. Bartleby, n. d. Web. 10 May 2012.

Wilde, Oscar. The Picture of Dorian Gray. Toronto: Oxford UP, 1981. Print. 